\title{
THE INRŌ COLLECTION IN THE NÁPRSTEK MUSEUM
}

\author{
Adéla Tưmová ${ }^{1}$
}

\begin{abstract}
Small several-compartment cases called inrō were a supplement to Japanese men's clothing during the Edo period and were used to store various small items (especially personal stamps). Decorated with various techniques, such as decorating with gold, nacre (mother of pearl), and inlaying with metals, they gradually became a decorative accessory for Japanese clothing. In the $19^{\text {th }}$ century inro became favorite collector' items in Europe. This article deals with inrō collection in the Náprstek Museum, its origin, but also with the techniques of inrō production.
\end{abstract}

KEYWORDS: inrō - box - stamp case - Japanese lacquer - Edo period - Japan

The second half of the $19^{\text {th }}$ century brought a growing interest in Japan and its culture. This interest, caused by the end of Japan's policy of isolation in 1868 and the opening of the country towards foreigners, aroused in Western society a desire for a deeper knowledge of the country, its culture, and Japanese items. Japanese influences were reflected in art in the form of Japan-inspired art, whether it was painting inspired by Japanese woodblock prints or literature ${ }^{2}$ where popular stories were inspired by the Far East. Although the Czech lands did not directly participate in Oriental trade and their contact with foreign countries was not as widespread as that of the colonial powers, the romanticizing view and interest in Japan also penetrated the Czech society. In 1884, Julius Zeyer published his novel Gompači a Komurasaki, ${ }^{3}$ which was inspired by the Japanese story of Gompachi's unhappy love for the beautiful courtesan Komurasaki, whose love story is a popular theme in the Japanese kabuki theatre. Zeyer drew his theme for the work partly from translated works, Zeyer himself mentioning Mitford's ${ }^{4}$ (1837-1916) stories. ${ }^{5}$ Other information was drawn from books about Japan available in Prague and Japanese items. It was in especially in Europe that the unusual decor of Japanese objects influenced Zeyer's contemporaries and evoked the idea of Japan as an exotic or nearly even fairy-tale-like country. ${ }^{6}$ Interest increased even more when the first travellers began to travel to Japan and publish their experiences in books or in the

1 Contact: Adéla Tůmová, National Museum - Náprstek Museum of Asian, African and American Cultures, Prague, Czech Republic; e-mail: adela.tumova@nm.cz. This work was financially supported by Ministry of Culture of the Czech Republic (DKRVO 2019-2023/ 19.I.c, National Museum, 00023272).

2 Abou-Jaoude 2016, pp. 57-82.

3 Zeyer 1884.

4 A. B. Mitford was a British aristocrat and diplomat who lived in Japan in the 1860s.

5 Mitford 1871.

6 'Japan, the strange and fantastic, which speaks to us so vividly and colourfully from harpoons, embroidered gauzes and atlases, screens and curtains, from fans, from lacquerware painted with gold, from vases and bowls made of fine enamel...'; Zeyer 1884, p. 8. 
form of lectures. ${ }^{7}$ Associated with the Náprstek Museum were, for example, Enrique Stanko Vráz (1860-1932), a Czech traveller who visited Japan in 1896, or Josef Kořenský (1847-1938). One of the first travellers to visit Japan in 1876 was Erwin Dubský (18361909), a frigate captain. He then exhibited the items he acquired during his travels to the public at his chateau in Lysice. ${ }^{8}$

Japan, which had practiced strict isolation since $1630 s,{ }^{9}$ was not completely unknown to Europeans. Dutch traders who were allowed to trade with Japan in the port of Nagasaki ${ }^{10}$ had been bringing porcelain and lacquered items from Japan to the European market. However, such items were luxury goods typical of wealthy aristocratic families and their decor was often made to suit the requirements of Dutch merchants, and therefore did not reflect Japanese style or taste. The items imported to Europe were primarily jewellery boxes and travel chests. ${ }^{11}$

It was not until the second half of the $19^{\text {th }}$ century that Japan introduced itself to broad strata of the European population. In addition to art and literature, exhibitions where foreign products were presented also played a role. The objects, often made and decorated with techniques or patterns that were unusual in Europe, were fascinating for Europeans and aroused collectors' interest in these goods. One of the first major presentations of Japanese goods was the World's Fair in London in 1862. ${ }^{12}$ Japanese objects were sent to London by Sir Rutherford Alcock (1809-1897), an envoy to Japan at the time who wanted to show the qualities of Japanese crafts in Europe. ${ }^{13}$ He was often commissioned by his friends abroad to buy and send them 'beautiful things from Japan', which he also considered very inexpensive. ${ }^{14}$ Exhibitions in Paris (1867) and Vienna (1873) soon followed. It was these exhibitions that re-introduced Japanese lacquerware and stimulated interest in both lacquered products produced in Japan for the foreign market and interest in older Japanese lacquerware. ${ }^{15}$

Among the lacquered items imported to Europe were also the inrō 印籠, multicompartment cases, which were a common accessory for Japanese clothing and hung from the $o b i$ 帯 belt ${ }^{16}$. After the Meiji restoration (1868), ${ }^{17}$ the Japanese began to prefer

7 In 1863, Vojta Náprstek's lecture on the topic of Japan and its art took place on Střelecký Island, supplemented by examples of Japanese items; Hánová 2010, pp. 40-41.

8 Suchomel and Suchomelová 2006, p. 40.

9 The policy of sakoku 鎖国 (closed country) was introduced by the shogun Tokugawa Iemitsu (16041651) in the 1630s, mainly due to fears of the possible influence of Christian missionaries and alliances of Catholic powers with Japanese feudal lords who might resist the Tokugawa shogunate.

10 The Dutch trading company was originally based on the island of Hirado near Nagasaki, but in 1641 it moved to the artificial island of Dejima in Nagasaki, originally the seat of Portuguese merchants who were expelled from Japan in 1638. Contacts with foreigners were reserved only for trusted officials, and the number of Dutch ships that were allowed to visit Dejima during the year was limited.

11 Suchomel and Suchomelová 2002, pp. 19-20.

12 Watanabe 1984, pp. 667-684.

13 'Specimens of the lacquer, porcelain, and bronze, many of them very choice and rare, I collected and sent to the Great Exhibition that it might be seen how far they would bear the test of close comparison with the best workmanship of Europe, and I think the result was by no means to the disparagement of the Japanese.'; Alcock 1863, p. 279.

14 Alcock 1863, pp. 278-279.

15 Suchomel and Suchomelová 2002, pp. 26-27.

16 A belt worn with traditional Japanese clothes.

17 The return of authority and reign to the emperor, which led to extensive reforms of society and the transformation of feudal Japan into a modern state. 
Western clothing, and the inrō lost its meaning. However, it gained popularity among foreigners, for whom inrō were an example of Japanese craftsmanship. In the eyes of the foreigners, these small, decorated cases represented an example of precise Japanese work and elegance, and they began to be collected along with other Japanese lacquered products. This trend of interest in lacquered items was also supported by the Japanese government, which specifically selected representatives of craftsmen for World Fairs. ${ }^{18}$ Inrō were produced for export even at a time when they were no longer worn in the Japanese culture and society. In this way, large private collections belonging to various collectors of Japanese items were created. Later, some of the items also reached European ethnographic museums.

The largest collections of inrō are located at the Victoria and Albert Museum in London (approximately 800 pieces), which include items from the collections of great collectors such as George Salting (1835-1909), William C. Alexander (1840-1916), or Sir Harry Garner $(1891-1977){ }^{19}$ and in the British Museum (346 inrō). ${ }^{20}$ Other large collections are in the Museé National des Arts Asiatiques-Guimet (250 inrō) or in the Museo d' Arte Orientale di Venezia (160 inrō). In Central Europe, the larger collections also include the collection in the Ferenc Hopp Museum of Eastern Asian Arts in Budapest (191 inrō), over 140 pieces come directly from the collection of the founder Ferenc Hopp, or the collection in the Muzeum Narodowe Krakowie (70 inrō). Another collection of inrō in Czech Republic is located in the Národní galerie Praha.

There are 52 inrō in the Náprstek Museum, of which 38 items come from the collection of Joe Hloucha and they arrived in the museum in the 1950s. Some of these inro have been exhibited at exhibitions focused on netsuke 根付 ${ }^{21}$ figures and jewellery, ${ }^{22}$ or are mentioned in studies dealing with Japanese lacquerware, ${ }^{23}$ however, a more detailed elaboration of the collection has not yet been carried out. The aim and purpose of this work is to describe the collection in the Náprstek Museum from a material point of view and to show whether it contains all types of inrō described in scholarly literature.

The first catalogues with lacquerware objects, including inrō, already appeared at the end of the $19^{\text {th }}$ century. These were often catalogues printed for exhibitions of Japanese art with a brief history of lacquerware or for auctions; they were often supplemented by photographic material. ${ }^{24}$ An example that we could state is the catalogue associated with the exhibition of Japanese metals in London. ${ }^{25}$ It was not until the 1960s that inrō began to be published in works on Japanese lacquerware ${ }^{26}$ or netsuke. ${ }^{27}$ One of the first books to focus exclusively on inrō is Raymond Bushell's work published in $1979 .{ }^{28}$ Since the early 1990s, inrō collections have been developed and exhibited in European

18 Kress and Kress 2005, p. 99.

19 Lacquer at the VEA 2016.

20 Inro 2020.

21 Netsuke is a miniature sculpture carved mostly from ivory or wood; Forman 1960.

22 Boháčková and Součková 1990.

23 Suchomel and Suchomelová 2002.

Catalogue of important and valuable Japanese work of art including lacquer, inro, netsuke, swords, and sword furniture: being the third portion of Gilbertson collection 1917.

Catalogue of specimens of Japanese Lacquer and Metal Work exhibited in 18941894.

Pekarik 1980.

Okada 1982.

Bushell 1979. 
museums, such as the inrō collection in the Victoria and Albert Museum ${ }^{29}$ or in the Linden Museum in Stuttgart. ${ }^{30}$

\section{Historical and cultural context}

Traditional Japanese clothing lacks pockets; ${ }^{31}$ therefore the items that the Japanese normally needed to carry with them (a handkerchief, fan, or knife) were placed in the bosom (in the space between the kimono's outer garment and the lower robe nagajuban 長襦袢 ${ }^{32}$ ) or in the sleeve pouch (tamoto 袂). Alternatively, they were worn tucked behind the obi belt. Items that could not be carried in this way were stored in cases that hung from the belt. These cases hung from the obi were called sagemono 提げ物, that is 'the hanging things'. Many such cases were manufactured to carry a particular type of item, be it pipe cases (kiseruzutsu 煙管筒) or calligraphic brushes and ink (yatate 矢立). Sagemono also includes inrō cases which were used to store and carry various small items. ${ }^{33}$

The name inrō or inro, (印籠) consists of two characters and could literally be translated as a 'stamp basket', where the character 印 means 'a stamp or a seal' and the character 籠 means 'a basket'. It was originally intended to store personal stamps, but today it is better known as a case in which medicines were stored (in English literature, inrō is often mistakenly translated as a 'pillbox').

Personal stamps and seals were commonly used in Asia instead of signatures, a custom that still continues to this day. The first documented seal came to Japan from China, and its use was reserved for the emperor or his chosen officials. In the $8^{\text {th }}$ century CE, the use of personal stamps spread among the court aristocracy. During the Kamakura period (1192-1333), personal stamps were already used even among the samurai. During the Edo period (1600-1868), trade began to develop, and a seal became a necessary requirement for traders who used it to sign contracts. ${ }^{34}$

Inrō cases appear in the Muromachi period (1333-1568). In addition to the need to store stamps and the colours in which the stamps were dipped, their growing popularity among the samurai and the wealthy urban population is often associated with an interest in foreign medicine. First Portuguese and later Dutch merchants brought medicinal drugs to the country. These medications had to be taken regularly; thus, inrō was suitable to carry them, since it was possible to carry several medicinal mixtures without their undesired mixing. ${ }^{35}$

During the $18^{\text {th }}$ and $19^{\text {th }}$ centuries, however, the function of inrō changed. The cases became more ornate and, rather than a functional accessory for carrying small items, began to serve as an ornament and status symbol - they were intended to show not only the wealth but also the taste of its wearer.

29 Hutt 1997.

Werlich 2016.

Winkelhöferová 1999. pp. 170-172.

Nagajuban is a simple kimono-shaped robe worn under the kimono to protect it from stains.

Okada 1982, pp. 9-11.

Pekarik 1980, pp. 22-24.

Pekarik 1980, pp. 23-24. 


\section{Description}

Most inrō have an elongated oval shape. They consist of several compartments that fit together and are connected by a string. The individual pieces (called dan 段) have an oval hole inside (naibu 内部), which represents a compartment in which medicines and small items were stored. The lowest piece is called chi 地, the upper piece ten 天. Because the bottom piece has a naibu compartment, it counts as a part. The upper piece does not have naibu and only serves as a lid. A four-case inrō consists of five parts - four dan pieces (which includes even the bottom piece chi) and then ten lid.

All parts of the inrō (including the bottom part and the lid) have a small round opening on their sides (himotoshi 紐通し). A silk cord was threaded through these holes, which held the individual pieces together and at the same time served to hang the inrō on the belt. There was a bead (ojime 緒締め) above the upper piece which served as a zipper of the threads. A netsuke - a small carved sculpture - was strung on the string. The silk cords stretched under the obi and the netsuke hooked behind the obi, serving as a counterweight to the inrō case. The free ends of the silk cord were then tied into a decorative knot under the lower piece.

Although inrō, ojime, and netsuke were made by different craftsmen, all these three parts were intended to form a complex whole together. It was common for inrō and netsuke to complement each other - the same decorations or materials were used for both or the netsuke figure motive complemented the inrō design. However, foreign collectors often focused only on the collection of individual parts, especially netsuke. Therefore, many inrō in European collections are incomplete. In the Náprstek Museum there are only nine inrō, which are complete, including ojime and netsuke (Inv. nos. 11599, 23183, 23184, 30049, 30050, 30051, 32068, 32070, A10936). Two inrō have only a netsuke figure (Inv. nos. 507, 32092) and one inrō has the ojime bead (Inv. No. 32089). A less common type are saya inrō 鞘印籠, which derive their name from the designation of a sword scabbard saya 鞘. These inrō consist of dan pieces as such and a saya case. Instead of the cord passing through each piece or part, it only passes through the case in which the pieces are placed.

\section{Japanese lacquer}

Japanese lacquer (urushi 漆) was used as a protective and covering material, because under suitable conditions (temperature $20-25^{\circ} \mathrm{C}$, humidity $70-80 \%$ ) it oxidizes, which causes the lacquer to harden; it becomes stable and highly resistant to weather conditions. The raw material for the production of lacquer is the sap of Chinese lacquer tree (Toxicodendron vernicifluum, formerly Rhus verniciflua), a plant endemic to the East Asian regions (India, China, Myanmar, Thailand, Japan). Sap is collected in the period from June to November. ${ }^{36}$ The sap, called arame or arami urushi 荒味漆, is then freed of impurities by filtration through paper and of excess water by heating. After filtering through paper, ki urushi (raw urushi 生漆) is formed, which contains a larger amount

36 The quality of the sap changes during this time. The best quality is obtained at the end of July and in August (called sakari-urushi 盛り漆, 'prime urushi') and is used to produce transparent or coloured lacquer for the final covering. Sap obtained in September (sue-urushi 末添, 'last urushi'), and October (urame-urushi 裏目漆, 'reverse urushi') contains less water and is mainly used as an adhesive or as a base layer of lacquer. 
of water. Ki urushi can be mixed with rice paste or flour to create a quality mugi urushi (urushi glue 麦漆). Only after a process called kurome クロメ ${ }^{37}$, when the ki urushi is heated and freed of excess water, transparent urushi (suki urushi 透漆, kijiro urushi 木 地呂漆) is obtained, which can be applied to items or coloured with pigments. Black lacquer $^{38}$ was created by adding ohaguro お歯黑 ${ }^{39}$ or soot; ${ }^{40}$ red lacquer by adding pigments from vermilion.

The technique of applying lacquer probably came to Japan from mainland China and its use has a long tradition in Japan. The oldest lacquered objects were found in the Tōhoku ${ }^{41}$ area and are dated approximately to the middle of the Jōmon $(14,000-$ 300 BCE). ${ }^{42}$

During the Asuka (538-710 CE) and Nara (710-794 CE) periods, interest in lacquered items increased even more, which was related to the arrival of Buddhism in Japan and the development of large temples. Buddhist objects as well as statues were decorated with lacquer. The large Buddhist statues in the Tōdaiji Temple ${ }^{43}$ were made by the method of dry lacquer (kanshitsu 乾漆), which came to Japan from China. The basis of these statues consisted of many layers of canvas dipped in lacquer, on which, after solidification, a mixture of lacquer, sawdust, clay, and other materials were applied, from which the details of the sculpture were modelled. ${ }^{44}$ At this time, lacquer trees began to be grown intentionally, and sap from the trees was often used to pay taxes. ${ }^{45}$

\section{Inrō types and their production}

The methods of production and decoration of inrō are quite diverse, individual cases can vary in shape, size, material, and number of pieces. The number of pieces that an inrō consists of can be variable. The most common are four-case inrō; there are 21 pieces of those in the collection of the Náprstek Museum. Less numerous are three-case inrō (14), two-case inrō (9), and five-case inrō (5). There are also inrō that have six or seven compartments, but none of those are in the collection. The inrō collection also includes three inrō cases, which consist only of the bottom piece and the lid; thus, they have only one compartment. These cases (Inv. nos. 512, 32070, 32074) differ from the others in shape, since they are wider; therefore, they maybe served not as cases for a seal or medicine, but as decorative cases for tobacco called tonkotsu $ん ん こ つ .{ }^{46}$

Inrō are most often classified according to the material used. Although lacquered inrō were produced most often, other materials such as wood or ivory were used as well.

From werb kurome 黒める, blackening.

While the lacquer from the trees in China is naturally dark, the sap from the trees in Japan is milky and becomes transparent during the treatment processes.

Japanese designation for a solution with an admixture of ferric acetate, which was commonly used to colour fabrics or blacken teeth (which was common in Japan for married women).

Matsuda 2019, pp. 78-79.

The north-eastern part of the island of Honshu.

Matsuda 2019, pp. 52-55.

Buddhist temple in the city of Nara, which was built in the $8^{\text {th }}$ century CE.

Mason 1993, pp. 65-66.

Matsuda 2019, p. 68.

Bushell 1979, pp. 141-148. 
The collection of the Krakow Museum includes an inrō made of coconut. ${ }^{47}$ Raymond Bushell's The Inrō Handbook also mentions porcelain, turtle shell, and snakeskin inrō ${ }^{48}$ However, even these inrō were often decorated with lacquer and lacquering techniques.

Most of the inrō in the collection are lacquered, although sometimes it is difficult to determine more precisely whether the inrō is lacquered or made of wood covered with lacquer. When it comes to other materials, the collection contains only five wooden inrō (Inv. nos. 11599, 32074, 32075, 32082, 39092) and four inrō made of ivory (Inv. nos. $32068,32069,32072,32095)$, all from the collection of Joe Hloucha.

Lacquered inrō were made of lacquer-covered paper, only the partitions between the individual pieces were made of wood, usually of Japanese cypress (Chamaecyparis obtusa), known in Japan as hinoki $ヒ ノ \neq$. Individual strips of paper, according to the number of the pieces of the specific inrō, were wrapped around a wooden mould, lacquered, and then allowed to dry in a cabinet called urushi muro (漆室) or simply muro ${ }^{49}$. To produce one inrō, two wooden moulds were needed; one was used for shaping the inner parts of the pieces, the other for shaping the outer shape of the inrō. Himotōshi (cord hole) were produced separately as well. Several types of Japanese lacquer were used to make inrō. After each application of one coat of lacquer on paper wrapped around the wooden mould, it was necessary to store the mould in a muro cabinet, allow the lacquer to harden properly, polish it, and only then apply another layer of lacquer. ${ }^{50}$

The individual parts were then glued together using mugi urushi (urushi glue) and again lacquered, dried, and polished several times. Only after the production of the inrō case as such was finished could the decoration itself take place. The inner parts of inrō are often decorated with a nashiji 梨子地 ${ }^{51}$ pattern, while various decorating techniques were used on the outward parts. The artist could design the decor himself or copy the design from ehon 絵本 woodblock printed books ${ }^{52}$, which included even inrō decoration motifs. ${ }^{53}$ Many artists did not sign their products. It is therefore impossible to determine exactly who and when produced a specific inrō. We find a signature on other inrō, but no details about the artists are known that would allow a more accurate dating of these inrō.

\section{Origins of the collection in the Náprstek Museum}

The oldest inrō additions (Inv. nos. 506, 507) in the collections of the Náprstek Museum date back to 1887, when they were donated to the museum by Josefa Náprstková (1838-1907). Josefa, the wife of the museum's founder Vojtěch Náprstek (1826-1894), donated many items from Asia and Africa to the museum. She did not

47 Kress and Kress 2005, p. 108.

48 Bushell 1979, pp. 126-127.

49 A type of cabinet, in which constant humidity and temperature, essential for drying lacquer, is maintained.

50 Bushell 1979, pp. 221-223.

51 A lacquering technique in which gold dust is poured into a moist layer of lacquer and thus creates a pattern similar to the skin of the Japanese nashi pear.

52 The ilustrated books popular in Japan during Edo period (1600-1868). Some ehon books displayed designs for kimono, netsuke and inrō decorating.

53 Bushell 1979, p. 226. 
choose the items herself but rather entrusted her friends and acquaintances with the task of buying them in shops in European capitals. ${ }^{54}$

In 1901, an item was purchased for the museum from Josef Kořenský (1847-1938), one of the first Czech travellers to Japan. The case (Inv. No. 512), made of wood and decorated with inlays of nacre, has only one compartment and is therefore possible that it served as a tobacco box. Josef Kořenský published a travelogue in which he describes Japan, its climate, agriculture and, indirectly, the beauty of lacquered objects: 'Many houses shine in such a way that they seem to be Japanese cabinets, whose great and durable paint is still unrivalled in our country. ${ }^{55}$ Kořenskýs travelogue was simultaneously designed to educate; therefore, during his travels he was also interested in the functioning of Japanese education and the production of various Japanese items. He visited, for example, workshops producing porcelain and tortoiseshell items, but not artists working with lacquer. In his travelogue he also mentions netsuke figures, which according to Kořenský belonged among smoking utensils. The question is whether Kořenský only knew tobacco boxes hung at the waist, or whether he also saw inrō as tobacco boxes. However, inrō were no longer widely used at the time of his visit.

In 1937, objects from the estate of Rưžena Trnožková (1868-1937) were donated to the museum. Not much information about Růžena Trnožková has been preserved. A letter ${ }^{56}$ which is located in the Náprstek Museum indicates that she was the wife of a general director of an export company for the East and a Czech patriot. On his travels he collected objects of Chinese and Japanese provenance, especially textiles. It is not known whether his wife travelled abroad with him. The inventory of the estate, which numbered 207 items, includes also four inrō (Inv. nos. 30048-30051), all of them beautifully decorated. Three inrō from Trnožková's collection are complete, including netsuke and ojime (Inv. nos. 30049-30051), inrō Inv. No. 30048 is richly inlaid with aogai 青貝 nacre. ${ }^{57}$ It is one of the two inrō in the collection which are decorated with this technique, typical for products from the Ryūkyū Islands. ${ }^{58}$ The other is Inv. No. A18654.

In 1951, the Liberation Memorial (Památník osvobození) ${ }^{59}$ donated 32 items of Japanese provenance to the museum (addition No. 87/51-120/51). These items came from the estate of Milan Rastislav Štefánik (1880-1919), ${ }^{60}$ who visited Japan in October

54 Jiroušková and Lukáš 2007.

55 Kořenský 1902, p. 53.

56 This is a letter from the lawyer Richard Aron, who dealt with the estate of Mrs. Trnožková. In Administrative documentation, folder 'Růžena Trnožková'. Letter from Richard Aaron to the director of the Náprstek Museum dated 14 August 1936.

57 A type of very thin nacre of bluish colour.

58 In the Ryūkyū Kingdom men did not wear kimono and inrō. Ryūkyūan inrō were made as gift for Japanese officials and later in the Meiji period as souvenir for foreigners. For more on the issue of Ryūkyūan inrō see Kress and Kress 2002.

59 A scientific institute which was established in 1929 by merging several institutions: Archive of Legions (Archiv legií), Archive of National Liberation (Archiv národního osvobození), Military Archive of the Czechoslovak Republic (Vojenský archiv RČS), and Military Museum of the Czechoslovak Republic (Vojenské muzeum RČS). During the Nazi occupation, the monument was discontinued. After 1945, the Military History Institute (Vojenský historický ústav) became the successor of the Memorial. The coup of 1948 marked a change in its concept, including questioning the importance of legionnaires.

60 Milan Rastislav Štefánik was a Slovak politician, diplomat, and astronomer. After the outbreak of World War I, he joined the French army and was the organizer of the Czechoslovak legions. 
1918. During his stay, he attended diplomatic meetings, but also: 'bought many nice Japanese art products, especially antique ones. He chose with great taste. ${ }^{61}$ Thus, two inrō became part of the collection. Both inrō are complete, with ojime and netsuke. One is decorated with black and coloured lacquer in rose relief (Inv. No. 23183), the other by golden maki-e (Inv. No. 23184).

The largest part of the inrō collection comes from the collection of Joe Hloucha. Hloucha's uncle was Josef Kořenský, and it was his travelogue and storytelling that aroused Hloucha's love for Japan when he was still a child. Despite the wishes of his parents, who hoped that he would take over the family business, he started working in the Náprstek Museum and studied foreign cultures. ${ }^{62}$ In 1906 and 1926, Hloucha made trips to Japan, where he even lived for some time. The items he bought on his travels and in European shops served him as inspiration in writing his works; at the same time, however, he considered the possibility of founding a Japanese museum. He collected Japanese woodblocks, metals, porcelain, sword guards, and netsuke figurines. Hloucha's collection is also the origin of a whole set of inrō (38 pieces; Inv. nos. 11597, 11599, 32068-32092, 32094-32104), most of which were gained by the museum in $1955,{ }^{63}$ when Hloucha donated his collections to the Náprstek Museum. ${ }^{64}$ Most of the inrō are lacquered with various types of decoration. All inrō made of ivory (Inv. nos. 32068, $32069,32072,32095)$ and the only inro decorated with the carved lacquer technique (Inv. No. 32099) in the possession of the Museum also come from Hloucha's collection.

In the second half of the $20^{\text {th }}$ century, the collection gained several more inrō, two purchased in 1967 from a private collector (Inv. No. A4230, A4231) and two from a store Klenoty (Jewellery) ${ }^{65}$ (Inv. No. A10936, A 12361). In 1988, items from the Moravian Museum in Brno were transferred to the Náprstek Museum. The only inrō (Inv. No. A18654) in the transfer came from the collection of Jindřich Blažej Vávra, also known as Heinrich Wawra Ritter von Fernsee (1831-1887), who served as a ship physician and surgeon in the Austro-Hungarian Navy. In the years 1872-1873, during a trip around the world, on which he accompanied the Saxon-Coburg princes, he also visited Japan.

\section{Conclusion}

There are 52 inrō in the collection of the Náprstek Museum. The oldest acquisition comes from Jindřich Vávra, who had brought his inrō from Japan. Much of the collection comes from the collection of Joe Hloucha, a well-known Japanophile and collector of Japanese items, who, however, did not directly focus on the products of the great masters. His collection thus contains mainly objects made in the $19^{\text {th }}$ century which were popular collector's item. The collection contains inrō made of usual materials, the most common are lacquer inrō (41 pieces). When it comes to other materials, inrō made

61 Písecký 1929, p. 104.

62 Kraemerová and Šejbl 2007, p. 10.

63 The gift agreement between Hloucha and National Museum made these objects part of the museum's collection, but the objects physically remained in possession of Hloucha until his death in 1956. In Administrative documentation, folder 'Hloucha'. The gift agreement between Joe Hloucha and National Museum in Prague. 25. IX. 1955, Ref. No. 62.539/1955.

64 Kraemerová and Šejbl 2007, p. 48.

65 Klenoty was state-owned enterprise during the Communist regime, that offered luxury goods, antiquities and 'oriental' items. 
of wood and ivory also appear in the collection. In comparison with the collections of other museums, the collection in the Náprstek Museum is an example of common collectors' production. Nevertheless, it still provides a helpful map of various techniques of decorating lacquerware.

No. 1

Woodblock

Dimensions: $35.7 \times 23.8 \mathrm{~cm}$

Acquisition: Joe Hloucha, 1955

Dating: 1839

Inv. No. $38258^{66}$

The author of the woodblock is Utagawa Kunisada ${ }^{67}$ (1786-1865). The sheet comes from the series Azuma hakkei no uchi: Hana sasō Yoshiwara no ya-u (東八景ノ内: 花誘吉原 の夜雨) (Eight views from the East: Evening rain in Yoshiwara attracting Japanese cherry blossoms) and depicts Kabuki theatre actor Nakamura Utaemon IV ${ }^{68}$ 中村歌右衛門 (1798-1852) in one of his roles. Kabuki actors often set fashion trends. Nakamura is wearing a black kimono with a brown obi belt. On the left side you can see a three-case red inrō case.

\section{No. 2}

Inrō

Dimensions: $7.5 \times 9 \times 2.5 \mathrm{~cm}$

Acquisition: Klenoty, 1976

Dating: $19^{\text {th }}$ century

Material: Lacquer, gold, metal

Inv. No. A $12361^{69}$

The case differs from other inrō by its robustness and unusual heart shape. Both the front and the back side are covered with golden okibirame 置平目. ${ }^{70}$ In the shakudo 赤 銅71 inserts, on the one side there is golden depiction of the ruler of hell, Yama, who is trying to drag away a smoking man; on the other side there is the yawning rakan Hattar Sonja ${ }^{72}$ with his tiger. The edges are decorated with Japanese cherry flowers on a golden nashiji. It is probably a product from the second half of the $19^{\text {th }}$ century intended for foreigners, as evidenced by both the unusual shape of the case and the considerable weight of the metal inserts, which would make it impossible to wear the inrō hung from the obi.

66 Published in Honcoopová, 2005, Cat. No. 070.

67 Also known as Utagawa Toyokuni III, one of the masters of woodcarving.

68 Actor in the Japanese kabuki theatre.

69 Published in Catalogue of Japanese Art in The Náprstek Museum 1994, Cat. No. 1328.

70 A lacquering technique in which larger grains of gold are poured into a moist thin layer of lacquer.

71 An alloy of gold and copper.

72 Rakan (arhat in Sanskrit) is a designation for a Buddhist disciple who has attained nirvana. There are several hundred rakans, the most famous in Japan being the Sixteen Rakans. 
No. 3

Inrō

Dimensions: $8.4 \times 4.5 \mathrm{~cm}$

Acquisition: Joe Hloucha, 1943

Dating: $19^{\text {th }}$ century

Material: Wood covered with lacquer, golden maki-e

Inv. No. $11599^{73}$

Inrō with three compartments. It is made of wood covered with a transparent lacquer to make the wood grain stand out. The decor is complemented by five leaves of Ginkgo biloba in golden maki-e, complemented by the techniques of tsukegaki 付描 ${ }^{74}$ and kirikane 切金. ${ }^{75}$ The inrō is signed 'Morimasa'.

No. 4

Inrō - tonkotsu

Dimensions: $5.9 \times 7 \mathrm{~cm}$

Acquisition: Joe Hloucha, 1955

Dating: $19^{\text {th }}$ century

Material: Wood, lacquer

Inv. No. 32074

This two-part case probably served as a tobacco box. It is carved from wood. It is partially covered with black and red lacquer, which creates the impression of a case. In the cartouches made of natural unlacquered wood, there is a motif of two Chinese children on the one side and a mountain pine motif on the other.

No. 5

Inrō

Dimensions: $9.5 \times 5.5 \mathrm{~cm}$

Acquisition: Joe Hloucha, 1955

Dating: $19^{\text {th }}$ century

Material: Ivory

Inv. No. $32072^{76}$

Inrō with three compartments made of ivory. It is decorated with the popular motif of the seven gods of fortune. ${ }^{77}$ On the one side, six of these gods are shown in a relief; on the other side a lowered relief shows the seventh god Bishamonten ${ }^{78}$ with a pagoda in his hand.

73 Published in Catalogue of Japanese Art in The Náprstek Museum 1994, Cat. No. 1308, Suchomel and Suchomelová 2005, Cat. No. 191.

74 Narrow lacquer lines sprinkled with gold or silver filings.

75 A decorative technique using thin sheets of cut-out gold or silver foil.

76 Published in Catalogue of Japanese Art in The Náprstek Museum 1994, Cat. No. 1324.

77 One of the lucky symbols often depicted on netsuke figures.

78 One of the seven gods of fortune and at the same time one of the Buddhist Four Heavenly Kings. He was the protector of the north and the ruler of rain. His symbol is a pagoda. 
No. 6

Inrō

Dimensions: $9 \times 5.9 \mathrm{~cm}$

Acquisition: Joe Hloucha, 1957

Dating: $19^{\text {th }}$ century

Material: Ivory

Inv. No. $32069^{79}$

Three-case ivory inrō. The relief carving depicts the gods of fortune Daikokuten and Ebisu $^{80}$ with a rod and fish on the one side and the god Fukurokuju with a staff ${ }^{81}$ on the other. The sides of the inrō are decorated with lotus leaves and flowers. The inrō was created by an unusual technique, since the individual pieces are not integral, but consist of several parts glued together. Signed 'Takachika'.

No. 7

Inrō

Dimensions: $7 \times 3 \mathrm{~cm}$

Acquisition: Růžena Trnožková

Dating: $19^{\text {th }}$ century

Material: Lacquer, paints

Inv. No. 30051

One of the less common saya-type inrōs. The individual pieces, which were used to store medicines and small items, do not have himotōshi openings through which the thread would pass; instead, they are stored in a case with a lid, and this case is then hung along the waist. The inrō is two-case, covered with golden nashiji, and the saya is covered with black lacquer and decorated with colourful horse motifs. The inrō also includes an ojime covered with lacquer and decorated with golden takamaki-e and a wooden netsuke in the form of a Buddhist mokugyo bell. ${ }^{82}$

No. 8

Inrō

Dimensions: $9.5 \times 4.9 \mathrm{~cm}$

Acquisition: Klenoty, 1974

Dating: $19^{\text {th }}$ century

Material: Lacquer, golden maki-e, metal

Inv. No. A10936

Five-case inrō covered with gold lacquer. It is decorated with a popular motif of a river and pine trees.

79 Published in Catalogue of Japanese Art in The Náprstek Museum 1994, Cat. No. 1320.

80 Gods of fortune. They are often depicted together. Daikoku was associated with wealth and crops, Ebisu with fishing.

81 A god of fortune associated with wisdom and longevity. His character probably had a type in Chinese legend, so he is depicted as a Chinese sage in a robe and with a cane.

82 Literally 'wooden fish' (木魚). It is a wooden instrument used in Buddhism and played on with a beater. It was often carved in the form of a fish or at least decorated with fish motifs. 
No. 9

Inrō

Dimensions: $8 \times 6.5 \mathrm{~cm}$

Acquisition: Joe Hloucha, 1957

Dating: $19^{\text {th }}$ century

Material: Carved Lacquer

Inv. No. 32099

Three-case inrō decorated with carved lacquer (tsuishu 堆朱). In two cartouches bordered by geometric ornaments (swastika, rhombuses), there is a waterfall with a vessel and a ladle on one side, and a Chinese scholar with an apprentice spreading ink on the other. The technique of carved lacquer had a long tradition in China, where it is documented during the Sung dynasty (960-1279). It consists in the application and subsequent drying of many lacquer layers which were subsequently carved into the desired pattern.

No. 10

Inrō

Dimensions: $8.2 \times 4.2 \mathrm{~cm}$

Acquisition: Joe Hloucha, 1955

Dating: $19^{\text {th }}$ century

Material: Wood

Inv. No. $32075^{83}$

Two-case inrō in the form of a bridge pillar, with its top covered with black lacquer. A centipede is gnawing through the pillar, which is a reference to a popular folk tale in which the hero Tawara Toda kills a giant man-eating centipede.

No. 11

Inrō

Dimensions: $8.5 \times 4.4 \mathrm{~cm}$

Acquisition: Moravian Museum Brno - collection of Jindřich Vávra

Dating: $19^{\text {th }}$ century

Material: Lacquer, nacre

Inv. No. A18654 ${ }^{84}$

Inrō decorated in the style of products from the Ryūkyū Islands. The decoration depicts a pagoda and a pine tree above a water on one side and a gazebo with a pine tree on the other. It is formed by inlay with a thin aogai nacre.

\section{Acknowledgements}

Photographs by Jiří Vaněk.

83 Published in Catalogue of Japanese Art in The Náprstek Museum 1994, Cat. No. 1309.

84 Published in Catalogue of Japanese Art in The Náprstek Museum 1994, Cat. No. 1323; Kraemerová 2005, p. 214; Suchomel and Suchomelová 2005, Cat. No. 200. 


\section{Literature:}

Abou-Jaoude, A. (2016). A Pure Invention: Japan, Impressionism, and the West, 18531906. The History Teacher, 50(1), pp. 57-82.

Alcock, R. (1863). The Capital of the Tycoon: A Narrative of Three Years Residence in the Japan. New York.

Boháčková, L. and Součková, J. (1990). Šperky a ozdoby z mimoevropského světa: katalog výstavy. Prague.

Bushell, R. (1979). The Inro Handbook: Studies of Netsuke, Inro and Lacquer. New York.

Catalogue of Japanese Art in The Náprstek Museum, (1994). Kyoto.

Catalogue of an important and valuable Japanese work of art including lacquer, inro, netsuke, swords, and sword furniture: being the third portion of Gilbertson collection, (1917). London.

Catalogue of specimens of Japanese Lacquer and Metal Work exhibited in 1894. (1894). London.

Forman, W. (1960). Japanese Netsuke. London.

Hánová, M. (2010). Japonismus ve výtvarném umění v Čechách. Prague.

Honcoopová, H. (2005). Kunisada: mistr pozdního japonského dřevořezu. Prague.

Hutt, J. (1997). Japanese Inro (Victoria and Albert Museum - Far Eastern Series. New York.

Jiroušková,J. and Lukáš, P., ed. (2007). V úctě nejhlubší Julius Zeyer (korespondence Julia Zeyera s manžely Náprstkovými). Prague.

Kořenský, J. (1902). Cesty po světě: Žaponsko. Prague.

Kraemerová, A. (2005). Naprstek Museum of Asian, African and American Cultures. In: Kreiner, J., Japanese Collections in European Museums II. Bonn, p.97-115.

Kraemerová, A. and Šejbl, J. (2007). Japonsko, má láska: český cestovatel a sběratel Joe Hloucha. Prague.

Kress, E. and Kress, H. (2002). Inro of the Ryūkyūs. Lacquered Medicine Containers. Bonn.

Kress, E. and Kress H. (2005). Inro Collecting and Collections in Europe. In: Kreiner, J., Japanese Collections in European Museums I. Bonn, pp. 203-215.

Mason, P. (1993). History of Japanese Art. New York. 
Matsuda, G. (2019). The Book of Urushi. Japanese Lacquerware from a Master. Tokyo.

Mitford, A. B. (1871). The Tales of Old Japan. London.

Okada, B. (1982). Netsuke: Masterpieces from the Metropolitan Museum of Art. New York.

Pekarik. A. (1980). Japanese Lacquer, 1600-1900: Selection from the Charles A. Greeneld Collection. New York.

Písecký, F. (1929). Generál M. R. Štefánik. Prague.

Suchomel, F. and Suchomelová, M., eds. (2006). Námořní deník Erwina Dubského. BrNo.

Suchomel, F. and Suchomelová, M. (2002). Plocha zrozená k dekoru. Japonské umění laku 16. -19. století. Prague.

The British Museum (2020). Inro [online]. Available at: https://britishmuseum.org/ collection/term/x7382?id=x7382\&page=4\#page-top [Accessed 5 Nov.2020].

Victoria and Albert Museum (2016). Lacquer at the V\&A [online]. Available at: http:// vam.ac.uk/content/articles/l/lacquer-at-the-v-and-a/ [Accessed 25 Sep. 2020].

Watanabe, T. (1984). The Western Image of Japanese Art in the Late Edo Period. Modern Asian Studies, 18(4), pp. 667-684.

Werlich, U. (2016). Inro: Japanese Belt Ornaments. The Trumpf Collection. Stuttgart.

Winkelhöferová, V. (1999). Dějiny odívání: Japonsko. Prague.

Zeyer, J. (1884). Gompači a Komurasaki. Prague.

\section{Archival sources:}

Administrative documentation, folder 'Růžena Trnožková'. Letter from Richard Aaron to the director of the Náprstek Museum dated 14 August 1936.

Administrative documentation, folder 'Hloucha'. The gift agreement between Joe Hloucha and National Museum in Prague. 25. IX. 1955, Ref. No. 62.539/1955. 
Pl. 1

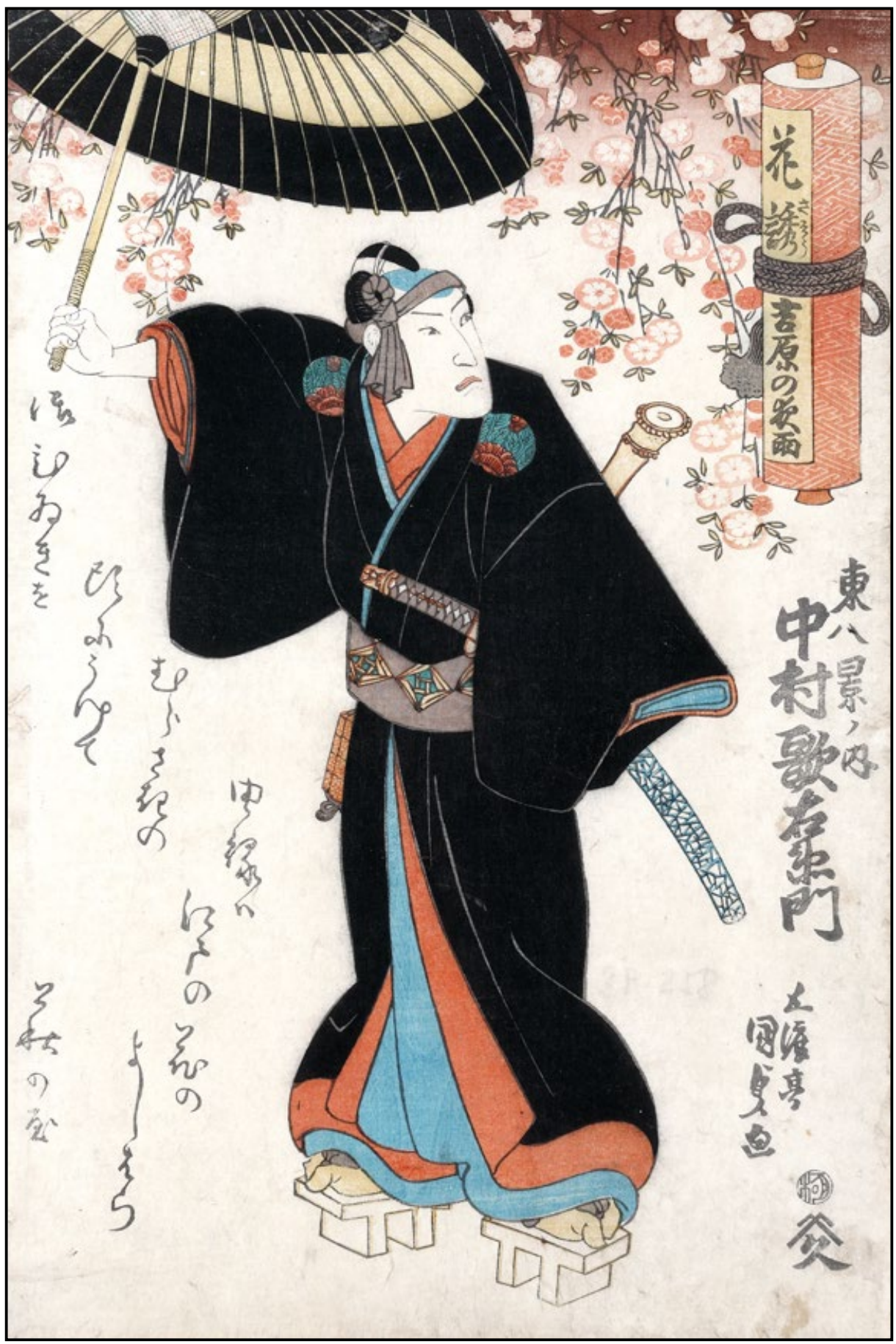

No. 1 


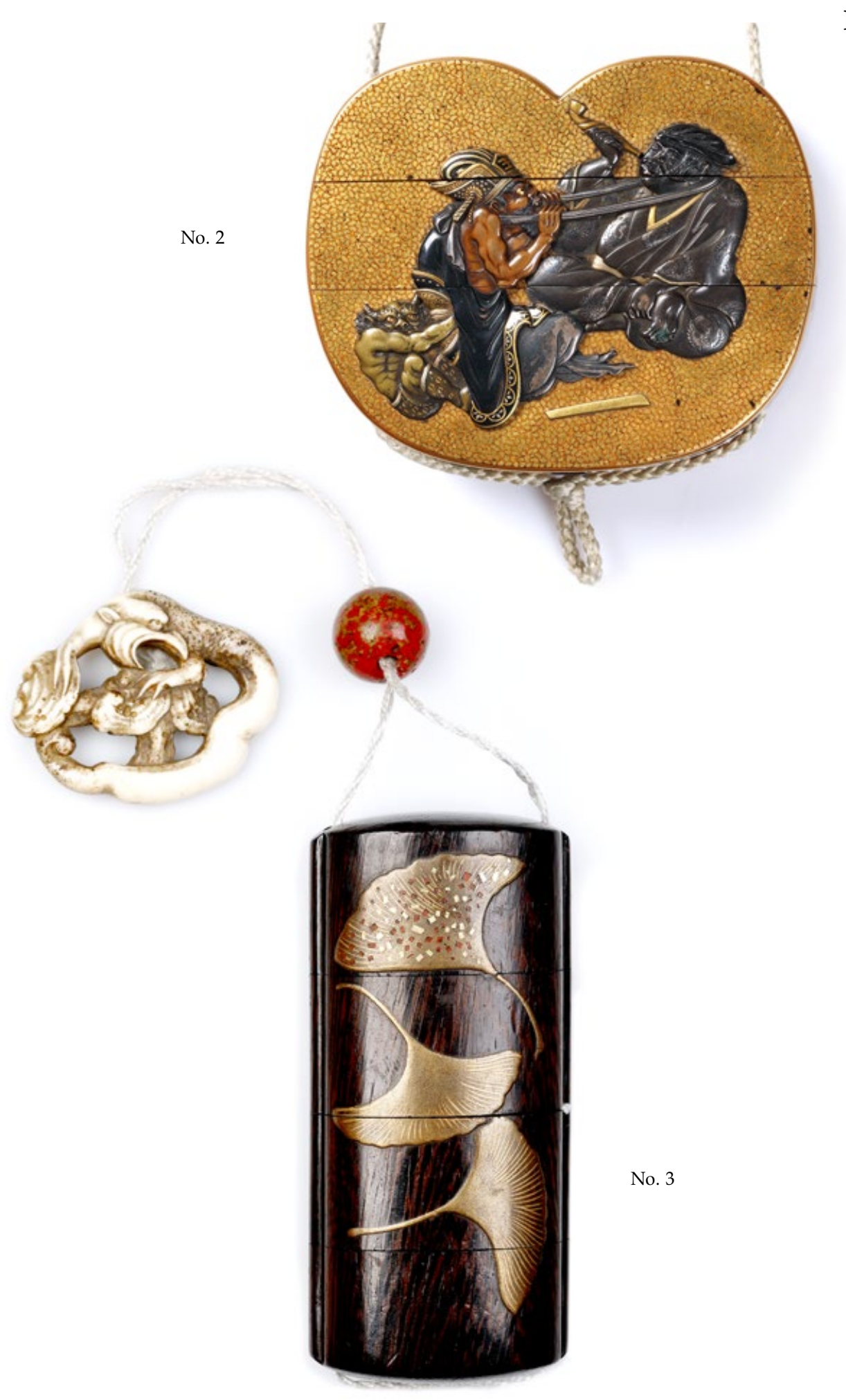

Pl. 2

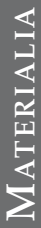


Pl. 3
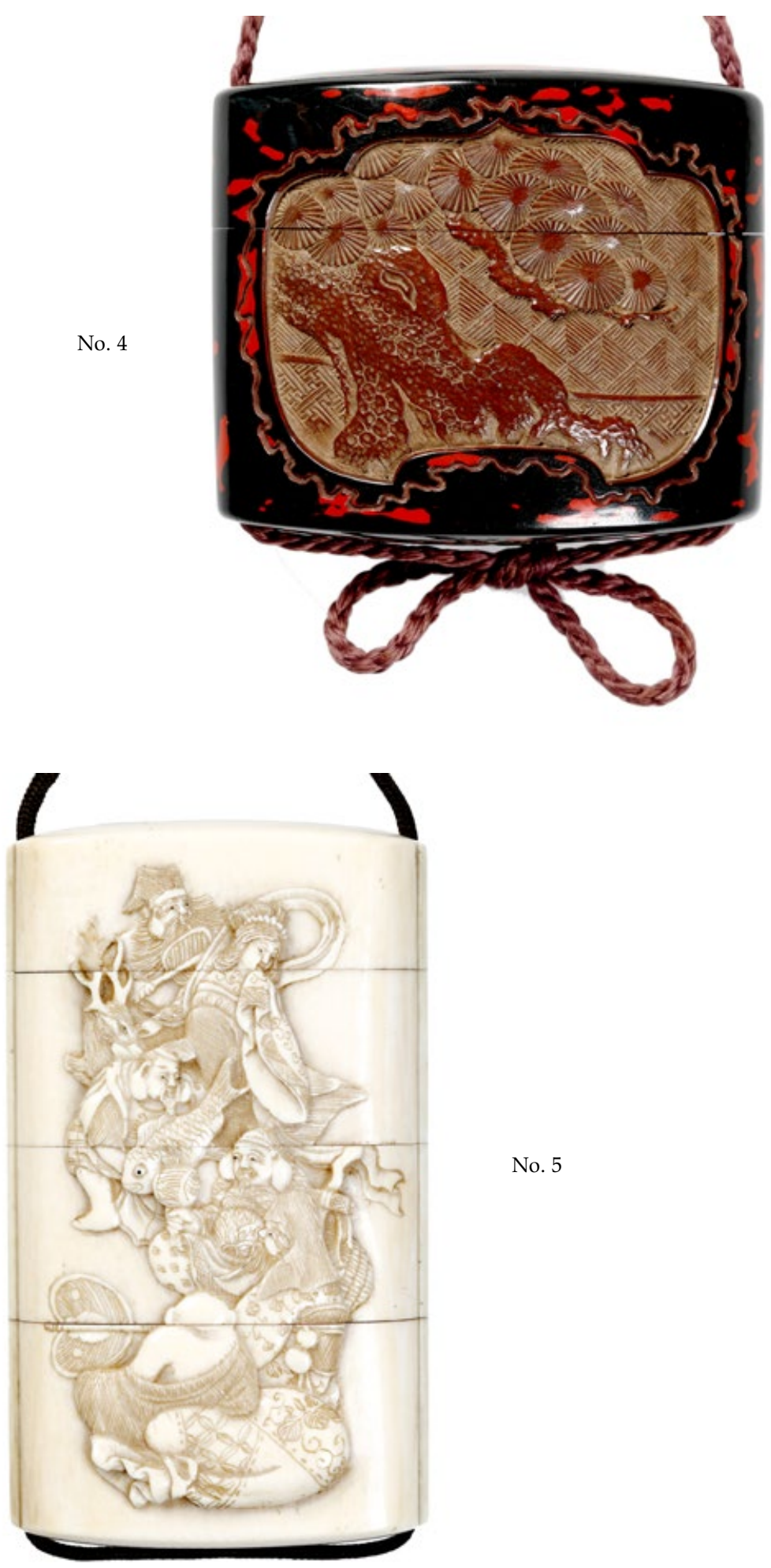

No. 5 


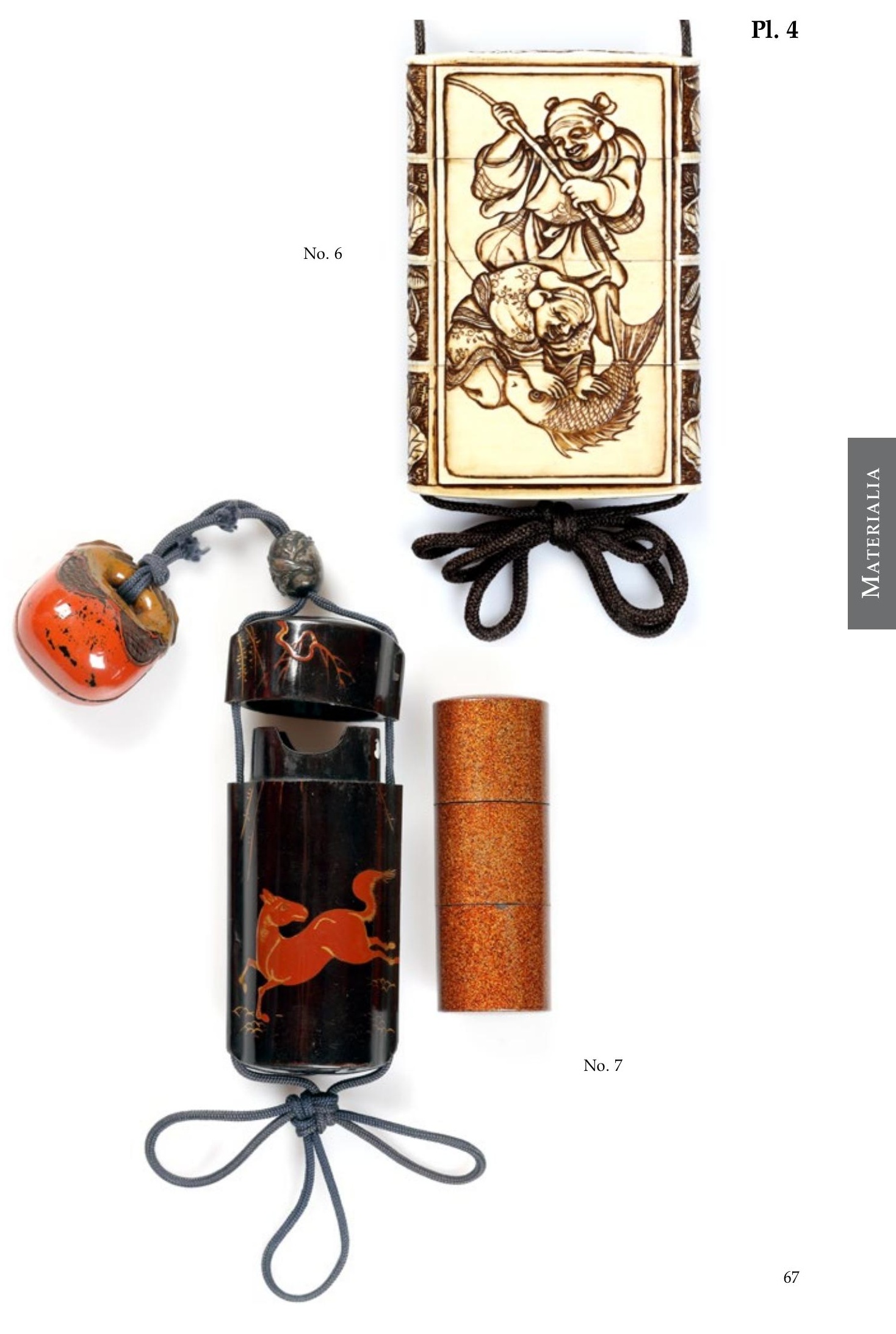


Pl. 5

No. 8

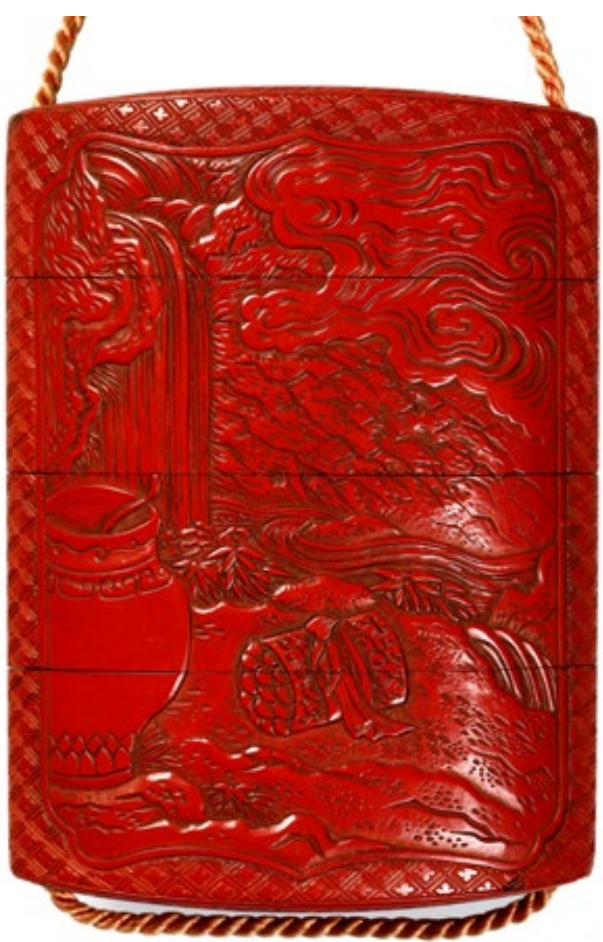

No. 9 

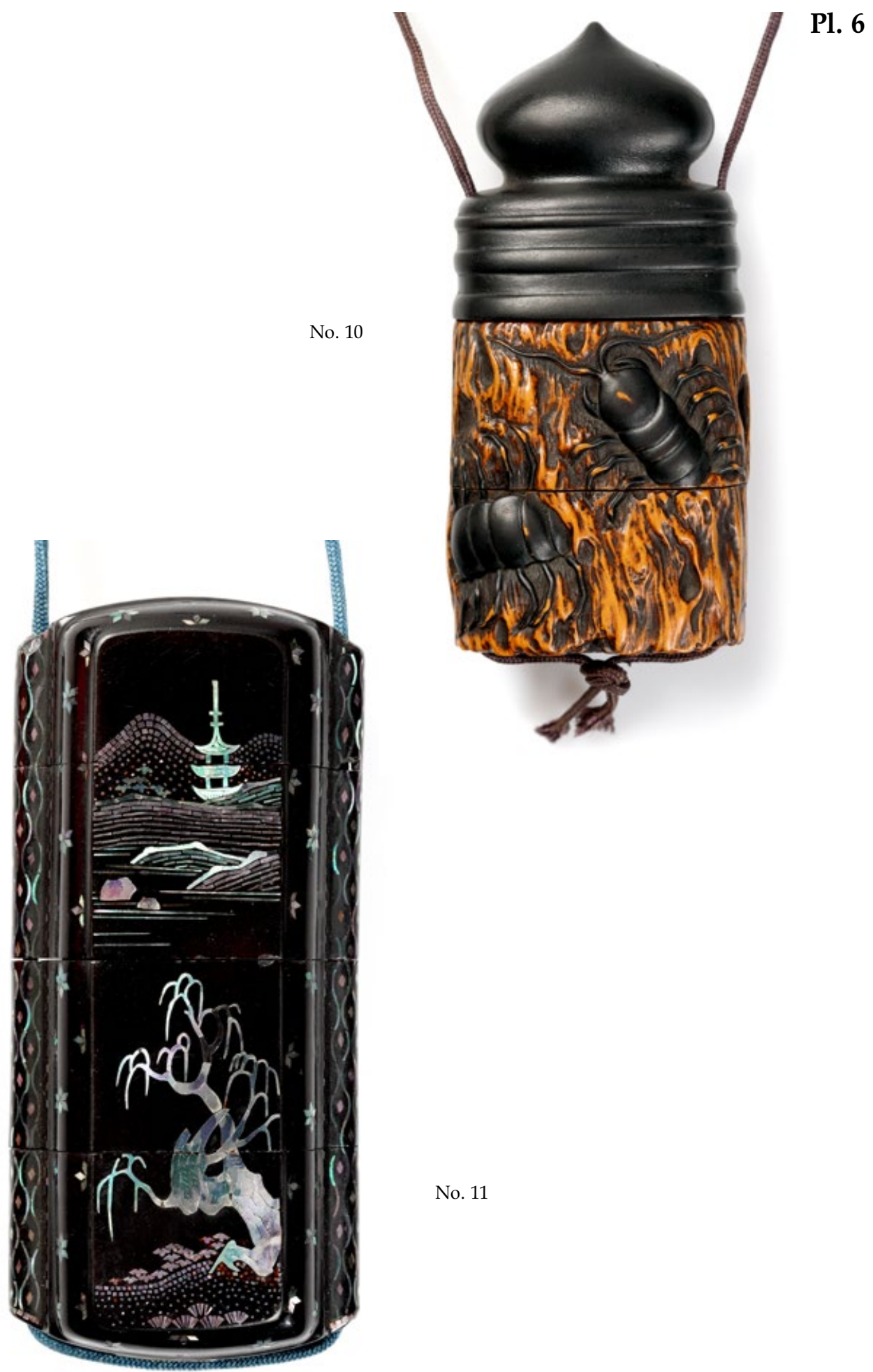

No. 10

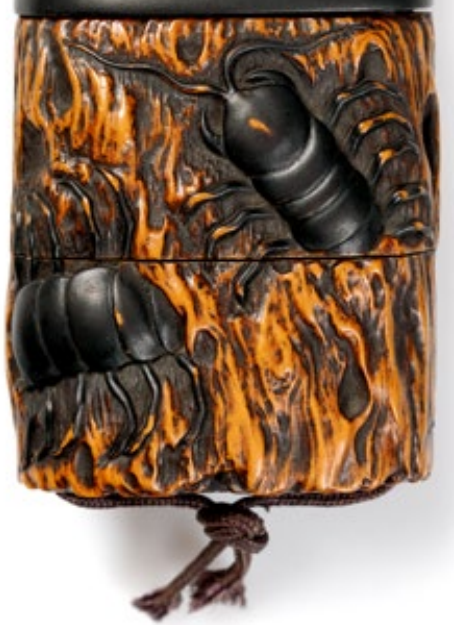

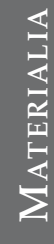

No. 11 